\title{
CONJUNCTIVAL AUTOGRAFTING IN THE SURGICAL MANAGEMENT OF PTERYGIUM
}

\author{
P. RIORDAN-EVA, I. KIELHORN, L. A. FICKER, A. D. McG. STEELE and C. M. KIRKNESS \\ London
}

\begin{abstract}
SUMMARY
In a retrospective survey of 117 operations for primary or recurrent pterygium, conjunctival autografting was compared with both excision without conjunctival closure ('bare sclera excision') and excision with complete conjunctival closure. The probability of corneal recurrence at 36 months after surgery was determined by survival curve analysis. In previously unoperated cases conjunctival autografting $(n=15)$ resulted in a $14 \%$ probability of recurrence, compared with $70 \%$ for bare sclera excision $(n=50)$ and $69 \%$ for excision with complete conjunctival closure $(n=20)$. In previously operated cases conjunctival autografting $(n=17)$ resulted in a $7 \%$ probability of recurrence, compared with $82 \%$ for bare sclera excision $(n=15)$. Hazard ratio analysis confirmed the statistical significance of these results at the $95 \%$ confidence level. Conjunctival autografting was more likely to produce an improvement in visual acuity than other forms of surgery.
\end{abstract}

The surgical management of pterygium is often complicated by the development of fibrovascular tissue, known as a 'recurrent pterygium'. This tends to be more aggressive in its growth pattern than the original lesion. Rates of recurrence in previously unoperated cases treated by simple surgical excision range from $32 \%{ }^{1}$ to $89 \%$. $^{2}$ Adjunctive treatment was introduced to reduce the rates of recurrence. But beta-irradiation, ${ }^{3,4}$ or anti-mitotic agents such as thiotepa ${ }^{5}$ and mitomycin, ${ }^{1,2,6,7}$ may also produce complications. More recently conjunctival autografting has been advocated as an effective method of reducing rates of recurrence. ${ }^{8}$

Conjunctival autografting for pterygium has been undertaken at Moorfields Eye Hospital since the 1970s, but the results have not previously been analysed. This retrospective review demonstrates the efficacy of the technique in reducing the probability of recurrence following pterygium excision, both in previously unoperated cases

From: Moorfields Eye Hospital, London, UK.

Correspondence to: Paul Riordan-Eva, FRCS, FRCOphth, Department of Neuro-Ophthalmology, National Hospital for Neurology and Neurosurgery, Queen Square, London WC1N 3BG, UK. and in those eyes with recurrences following previous surgery. The safety of the procedure is also established.

\section{MATERIALS AND METHODS}

Patients who underwent surgery for pterygium between January 11980 and December 311990 by the Corneal Service of Moorfields Eye Hospital were identified from the operating theatre record books. All patients were contacted by letter to attend for review by the authors.

The patient's personal details and information on the clinical details and management of the pterygium were obtained from the patient or from the hospital notes. The indications for surgery included reduced visual acuity, ocular surface discomfort and poor cosmesis.

All eyes had undergone simultaneous excision of the corneal, conjunctival and episcleral components of the pterygium. To be included in the study the operative procedure must have involved all three of the following:

1. Surgery for nasal pterygium only.

2. Keratectomy excision of the corneal component without keratoplasty.

3. The conjunctival defect was either:

i) left unsutured ('bare sclera excision')

ii) closed completely with sutures ('complete conjunctival closure') or

iii) filled with a free graft of bulbar conjunctiva, usually from the supero-temporal quadrant of the same eye (Fig. 1) ('conjunctival autograft')., ${ }^{8,9}$ Such grafts included limbal stem cells and were orientated to place these at the limbus of the recipient site.

Patients were excluded if they had been treated postoperatively with radiotherapy, laser or anti-mitotic agents. Results of histopathological investigations were checked to ensure the diagnosis of pterygium or of fibrovascular proliferation subsequent to previous pterygium surgery.

Outcome was determined by clinical recurrence involving the cornea, defined as the presence of both fibrous and vascular tissue encroachment across the limbus. The extent and nature of such recurrences were determined by clinical examination in those patients attending for review, 

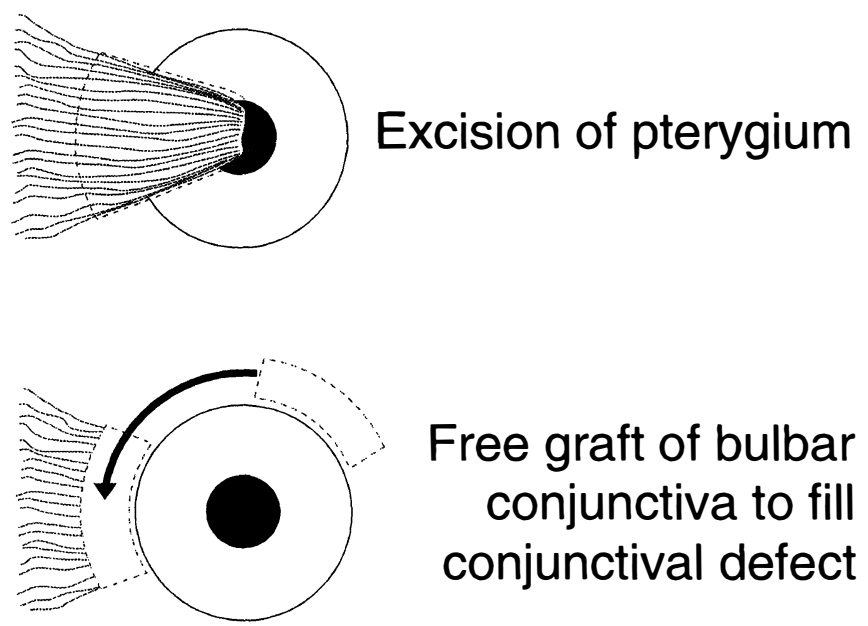

Fig. 1. Conjunctival autografting following pterygium excision (left eye).

and from the hospital notes in the remainder. The time of recurrence was obtained from the hospital notes.

Statistical analysis of corneal recurrences was based on survival curves using the Kaplan-Meier product limit technique supplemented by confidence interval analysis of hazard ratios. ${ }^{10}$ In those patients in whom the last hospital record showed no recurrence but a recurrence was found at review and more than 6 months had elapsed between the two examinations, the timing of the final examination at which no recurrence was found was entered as the duration of disease-free follow-up. Survival curves were produced for each of the surgical subgroups.

Table I. Details of previous surgery, surgical technique and follow-up date

\begin{tabular}{|c|c|c|c|}
\hline & $\begin{array}{l}\text { Bare } \\
\text { sclera } \\
\text { excision }\end{array}$ & $\begin{array}{l}\text { Complete } \\
\text { conjunctival } \\
\text { closure }\end{array}$ & $\begin{array}{l}\text { Conjunctival } \\
\text { autograft }\end{array}$ \\
\hline \multicolumn{4}{|l|}{ A. No previous surgery } \\
\hline No. of eyes & 50 & 20 & 15 \\
\hline $\begin{array}{l}\text { Eyes reviewed by authors } \\
\text { (\% of subgroup) }\end{array}$ & $\begin{array}{c}20 \\
(40)\end{array}$ & $\begin{array}{c}9 \\
(45)\end{array}$ & $\begin{array}{c}6 \\
(40)\end{array}$ \\
\hline $\begin{array}{l}\text { Range of follow-up } \\
\text { (months) }\end{array}$ & $1-132$ & $1-120$ & $3-37$ \\
\hline $\begin{array}{l}\text { Average follow-up } \\
\text { (months) }\end{array}$ & 39 & 37 & 15 \\
\hline $\begin{array}{l}\text { Eyes followed for } \\
<3 \text { months } \\
\text { (\% of subgroup) }\end{array}$ & $\begin{array}{c}6 \\
(12)\end{array}$ & $\begin{array}{c}3 \\
(15)\end{array}$ & $\begin{array}{c}0 \\
(0)\end{array}$ \\
\hline $\begin{array}{l}\text { Eyes followed for } \\
>12 \text { months } \\
\text { (\% of subgroup) }\end{array}$ & $\begin{array}{c}30 \\
(60)\end{array}$ & $\begin{array}{c}14 \\
(70)\end{array}$ & $\begin{array}{c}8 \\
(53)\end{array}$ \\
\hline \multicolumn{4}{|l|}{ B. Previous surgery } \\
\hline No. of eyes & 15 & & 17 \\
\hline $\begin{array}{l}\text { Eyes reviewed by authors } \\
\text { (\% of subgroup) }\end{array}$ & $\begin{array}{c}8 \\
(53)\end{array}$ & & $\begin{array}{c}12 \\
(71)\end{array}$ \\
\hline $\begin{array}{l}\text { Range of follow-up } \\
\text { (months) }\end{array}$ & $1-129$ & & $1-95$ \\
\hline $\begin{array}{l}\text { Average follow-up } \\
\text { (months) }\end{array}$ & 60 & & 32 \\
\hline \multicolumn{4}{|l|}{ Eyes followed for } \\
\hline $\begin{array}{l}<3 \text { months } \\
\text { (\% of subgroup) }\end{array}$ & $\begin{array}{l}1 \\
(7)\end{array}$ & & $\begin{array}{c}2 \\
(12)\end{array}$ \\
\hline $\begin{array}{l}\text { Eyes followed for } \\
>12 \text { months } \\
\text { (\% of subgroup) }\end{array}$ & $\begin{array}{l}11 \\
(73)\end{array}$ & & $\begin{array}{c}12 \\
(71)\end{array}$ \\
\hline
\end{tabular}

Chi-square and Wilcoxon rank sum tests were used to analyse for factors associated with the development of recurrence.

\section{RESULTS}

One hundred and fifty patients were identified as having undergone pterygium surgery during the 11-year study period. The notes of 115 patients $(77 \%)$ were available. Of these, $48(42 \%)$ attended for review. The 115 patients had undergone 146 operations.

The inclusion and exclusion criteria reduced the study group to 117 operations (52 left eyes and 65 right eyes) in 108 patients ( 66 male and 42 female, with ages at the time of surgery ranging from 25 to 77 years and averaging 47 years). The major racial groups were West Indians (28\%), Mediterraneans (15\%), individuals from the Indian subcontinent (14\%), British (14\%) and Africans (11\%).

The type of surgery undertaken, whether previous pterygium surgery had been performed, and the details of the post-operative follow-up, including the proportion of eyes examined by the authors, are given in Table I. The details of the recurrences following surgery are given in Table II and Fig. 2, and the results of the hazard ratio analyses are given in Table III.

At 36 months after surgery, the probabilities of recurrence in previously unoperated eyes were $69-70 \%$ for eyes not undergoing conjunctival autografting and $14 \%$ for those undergoing conjunctival autografting, and the hazard ratios ranged from 3.87 to 5.21. For previously operated eyes the probabilities of recurrence were $82 \%$ for

Table II. Recurrence data

\begin{tabular}{|c|c|c|c|}
\hline & $\begin{array}{c}\text { Bare } \\
\text { sclera } \\
\text { excision }\end{array}$ & $\begin{array}{l}\text { Complete } \\
\text { conjunctival } \\
\text { closure }\end{array}$ & $\begin{array}{c}\text { Conjunctival } \\
\text { autograft }\end{array}$ \\
\hline \multicolumn{4}{|l|}{ A. No previous surgery } \\
\hline No. of eyes & 50 & 20 & 15 \\
\hline Total recurrences & 31 & 14 & 2 \\
\hline Crude recurrence rates $(\%)$ & 62 & 70 & 13 \\
\hline \multicolumn{4}{|l|}{ Recurrences occurring } \\
\hline $\begin{array}{l}\text { before } 3 \text { months } \\
\text { (\% of subgroup's } \\
\text { recurrences) }\end{array}$ & $\begin{array}{c}16 \\
(52)\end{array}$ & $\begin{array}{c}6 \\
(43)\end{array}$ & $\begin{array}{c}1 \\
(50)\end{array}$ \\
\hline \multicolumn{4}{|l|}{ Recurrences occurring } \\
\hline before 12 months & 26 & 11 & 2 \\
\hline $\begin{array}{l}\text { (\% of subgroup's } \\
\text { recurrences) }\end{array}$ & $(84)$ & (79) & $(100)$ \\
\hline $\begin{array}{l}\text { Probabilities of recurrence } \\
\text { at } 36 \text { months }(\%) \text { (survival } \\
\text { curve analysis) }\end{array}$ & 70 & 69 & 14 \\
\hline \multicolumn{4}{|l|}{ Previous surgery } \\
\hline No. of eyes & 15 & & 17 \\
\hline Total recurrences & 11 & & 1 \\
\hline Crude recurrence rates $(\%)$ & 73 & & 6 \\
\hline \multicolumn{4}{|l|}{ Recurrences occurring } \\
\hline $\begin{array}{l}\text { before } 3 \text { months } \\
\text { (\% of subgroup's } \\
\text { recurrences) }\end{array}$ & $\begin{array}{c}5 \\
(45)\end{array}$ & & $\begin{array}{c}1 \\
(100)\end{array}$ \\
\hline \multicolumn{4}{|l|}{ Recurrences occurring } \\
\hline before 12 months & 11 & & 1 \\
\hline $\begin{array}{l}\text { (\% of subgroup's } \\
\text { recurrences) }\end{array}$ & $(100)$ & & $(100)$ \\
\hline $\begin{array}{l}\text { Probabilities of recurrence } \\
\text { at } 36 \text { months }(\%) \text { (survival } \\
\text { curve analysis) }\end{array}$ & 82 & & 7 \\
\hline
\end{tabular}




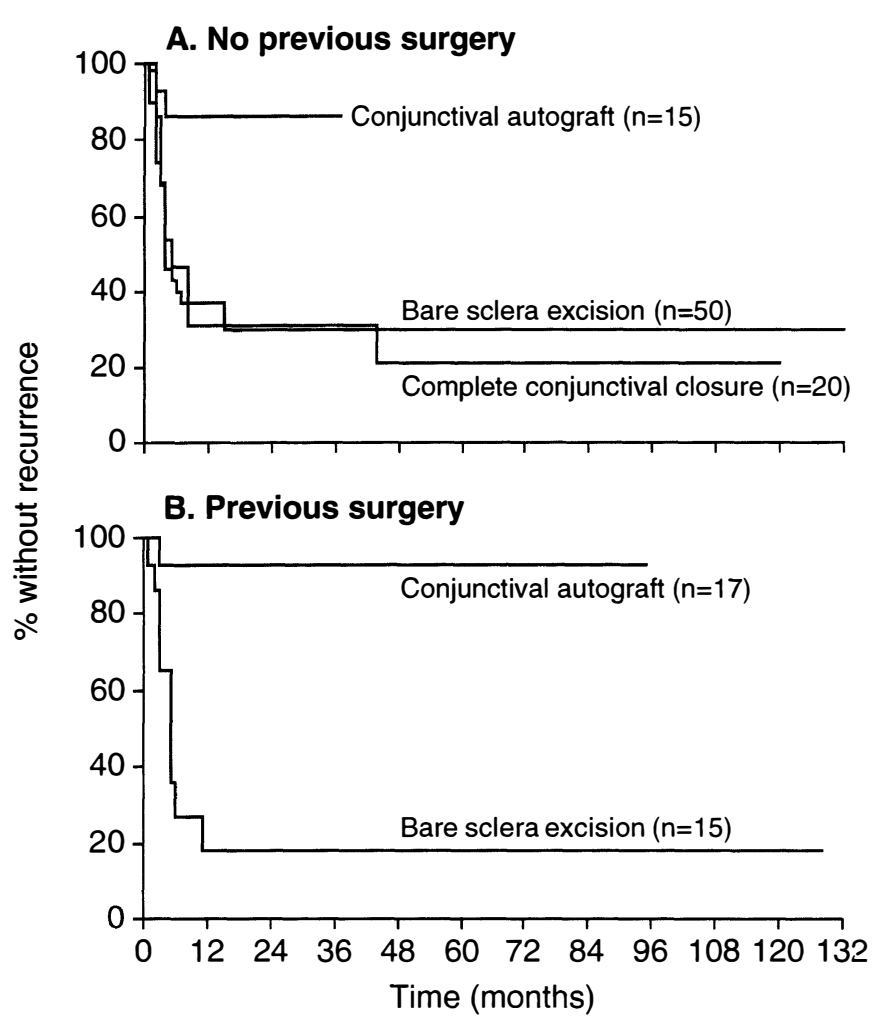

Fig. 2. Probability of corneal recurrence following pterygium surgery (Kaplan-Meier survival curves).

bare sclera excision and $7 \%$ for conjunctival autografting, with a hazard ratio of 11.5. Confidence interval analysis confirmed that the hazard ratios were well within statistical significance at the $95 \%$ confidence level.

Of the previously unoperated eyes not treated by conjunctival autografting, the relative risk for corneal recurrence was 2.2 with respect to a patient living outside Northern Europe for more than 20 years prior to surgery. There was no statistical association $(p<0.1)$ between the development of corneal recurrence and age, sex, duration of pterygium, presence of pterygium in the fellow eye, or duration of post-operative steroid treatment for any of the surgical groups. The information available on size of pterygium prior to surgery was insufficiently precise to allow determination of any association with rates of corneal recurrence. It was also not possible to determine the rates of corneal recurrence for individual surgeons.

There was no significant difference between the eyes in which outcome was verified by examination and those for which the outcome was obtained from the notes in terms of the patient's age or sex, the duration of the pterygium, years spent outside Northern Europe, duration of post-

Table III. Hazard ratios (ratio of probability of recurrence after other surgery to probability of recurrence after conjunctival autografting) at 36 months with $95 \%$ confidence intervals

\begin{tabular}{ll}
\hline A. No previous surgery & \\
Bare sclera excision & $3.87(1.61-9.30)$ \\
Complete conjunctival closure & $5.21(1.67-16.2)$ \\
B. Previous surgery & \\
Bare sclera excision & $11.5(3.60-37.0)$ \\
\hline
\end{tabular}

operative steroid treatment, or the probability or timing of corneal recurrence.

The effect of surgery on the visual acuity of eyes not developing a recurrence is given in Table IV. Of the 2 eyes in the previously operated group treated by conjunctival autografting which sustained a reduction in visual acuity, 1 had a pre-operative acuity of $6 / 18$ with a +1.50 sphere, which could be improved to $6 / 6$ with $+7.50-7.00 \times 172$. Post-operatively the acuity with a +1.50 sphere was $6 / 36$ improving to $6 / 24$ with a pinhole. The patient was not refracted further. In the second case the patient was lost to follow-up at 2 months after surgery with an uncorrected acuity of 6/12, having had a corrected acuity of $6 / 5$ pre-operatively.

Delayed corneal epithelialisation, defined as a corneal epithelial defect that failed to heal within 3 days of surgery, did not occur after surgery for recurrent pterygium. After surgery for primary pterygium it occurred in $6 \%$ of eyes undergoing bare sclera excision, $10 \%$ of eyes undergoing excision with complete conjunctival closure, and in $7 \%$ of eyes after conjunctival autografting. Diplopia occurred in 2 patients. In 1 previously operated eye undergoing conjunctival autografting, pre-operatively there was restriction of abduction with diplopia on lateral gaze. This was not increased by the autograft surgery and there was no recurrence of the pterygium. Subsequent recession of the medial conjunctiva with excision of Tenon's capsule and post-operative beta-irradiation returned the ocular motility to normal. In another previously operated eye the medial rectus was inadvertently detached at the time of a bare sclera excision; it was reattached at the time of surgery. Post-operative diplopia was successfully controlled with base-out prisms. A corneal delle occurred after conjunctival autografting in 1 eye that had undergone previous surgery. In none of the eyes treated by conjunctival autografting were there any problems at the donor site.

Histopathological examination confirmed the diagnosis of pterygium or of fibrovascular proliferation subsequent to previous pterygium surgery in the 22 specimens available.

\section{DISCUSSION}

The major problem in the management of pterygium is recurrence after surgical excision. Conjunctival autograft-

Table IV. The effect of surgery on visual acuities of eyes not developing a recurrence

\begin{tabular}{lccc}
\hline & \multicolumn{2}{c}{$\begin{array}{c}\text { Change in visual acuity (2 or more } \\
\text { Snellen lines) with surgery } \\
(\%)\end{array}$} \\
\cline { 2 - 4 } & Improved & Unchanged & Worse \\
\hline $\begin{array}{l}\text { A. No previous surgery } \\
\text { Bare sclera excision or } \\
\quad \text { complete conjunctival } \\
\text { closure }\end{array}$ & 12 & 88 & 0 \\
Conjunctival autograft & 54 & 46 & 0 \\
$\begin{array}{l}\text { B. Previous surgery } \\
\text { Bare sclera excision }\end{array}$ & & & \\
Conjunctival autograft & 0 & 100 & 0 \\
\hline
\end{tabular}


ing has been reported to produce a low recurrence rate in an uncontrolled series of advanced and recurrent pterygia ${ }^{8}$ but no significant improvement over the bare sclera technique was found in a prospective randomised trial conducted in the Caribbean. ${ }^{11}$ This retrospective survey attempts to produce a more definitive answer.

Retrospective studies are recognised to have particular limitations. The relevant limitations in this study are the partial reliance on case notes for the determination of outcome and the short duration of follow-up in a significant proportion of cases. The first of these limitations is overcome by the authors having personally reviewed $42 \%$ of the patients studied, and the demonstration that there was no significant difference in the relevant pre-operative or post-operative factors or the outcome between eyes in which outcome was verified by this review and those for which outcome was determined from the case notes. The variability of follow-up is overcome by the statistical technique of survival curve analysis by the Kaplan-Meier product limit together with confidence interval analysis of hazard ratios.

In this large survey conjunctival autografting produced an almost fourfold reduction in the probability of corneal recurrence after surgery for primary pterygium compared with bare sclera excision, and a greater than fivefold reduction compared with complete conjunctival closure. The probability of corneal recurrence after surgery for recurrent pterygium was reduced more than 11 -fold by conjunctival autografting compared with bare sclera excision. Thus for both primary and recurrent pterygia conjunctival autografting produced highly significant clinical differences in probability of recurrence and this is supported by clear statistical differences at the $95 \%$ confidence level.

In the previously reported randomised prospective study from the Caribbean, there was a reduction in rates of recurrence with conjunctival autografting compared with bare sclera excision but this did not reach statistical significance. ${ }^{11}$ The stated recurrence rates were $21 \%$ after conjunctival autografting and $37 \%$ after bare sclera excision, although the detailed results show a recurrence rate in the conjunctival autograft group of only $16 \%$. This still does not reach a statistically significant difference using Fisher's exact test, which was the statistical method chosen for that study. In the article it was suggested that the absence of a statistically significant difference might have been due to the relatively small sample sizes ( 16 bare sclera cases and 19 grafted cases) rather than the absence of a true difference. It may well be that in the tropics the difference in rate of recurrence produced by conjunctival autografting over other forms of surgery is relatively smaller than in non-tropical areas, possibly because of the continuing exposure to environmental factors such as high ultraviolet light levels, and that a larger study would be needed to demonstrate a statistical difference. A major criticism of this Caribbean study must, however, be the failure to employ survival curve analysis to determine the probabilities of recurrence.
In this study, the probability of recurrence in eyes undergoing bare sclera excision for primary pterygium was 70\%, even though the patients continued to reside in England. This figure is comparable to those reported in studies from The Netherlands $(74 \%)^{4}$ and North America $\left(89 \%,{ }^{2} 73 \%{ }^{7}\right.$ and $\left.55 \%{ }^{3}\right)$, but is much higher than those in a study from Japan $(32 \%)^{1}$ and the above-mentioned Caribbean study $(40 \%) .{ }^{11}$ This suggests that the factors determining rates of recurrence after surgery are different from those determining the development of pterygium, as might be expected from the differences in histopathology. It is surprising that the recurrence rates are so much lower in the Caribbean and Japan than in Northern Europe and North America. This partly reflects differences in definition of recurrence. In the Caribbean study a recurrence was defined as regrowth of pterygium to the pre-operative size or larger and the presence of symptoms. In the Japanese study recurrence was defined as post-operative regrowth of fibrovascular tissue similar to the original pterygium. In the North American study with a 73\% recurrence rate, recurrence was defined as corneal encroachment by fibrovascular tissue of at least $1.5 \mathrm{~mm}$ with conjunctival drag. In the other North American studies and the study from The Netherlands no definition of recurrence was given. In this study a very rigorous definition was employed: any encroachment across the limbus of fibrous and vascular tissue was deemed to be a recurrence. If this definition is applied to the Caribbean study the rate of recurrence for bare sclera surgery in previously unoperated eyes increases to $53 \%$.

Why conjunctival autografting reduces the probability of corneal recurrence is still uncertain. There are a number of factors that may be important:

1. Limbal stem cells are purposefully included in the transplanted conjunctiva and are then correctly orientated at the limbus of the pterygium excision site.

2. The transplanted conjunctiva does not include episcleral tissue.

3. The complete closure of the excision site with relatively normal conjunctival tissue provides a 'fire-break' to the proliferation and advancement of residual abnormal tissue, both conjunctival and episcleral, towards and across the limbus.

The two major alternatives to conjunctival autografting for reducing pterygium recurrence are adjunctive betairradiation and post-operative anti-mitotic agents, of which mitomycin is now the preferred agent. These produce similar dramatic reductions in recurrence rates compared with bare sclera excision. ${ }^{1-7}$ Beta-irradiation is associated with significant complications, most notably scleral necrosis which may occur many years later and lead to endophthalmitis. ${ }^{12,13}$ Mitomycin drops are usually administered for 5-14 days after surgery although, as suggested by research into glaucoma surgery, a single peroperative application may be sufficient. ${ }^{14,15}$ There are, however, many reported side effects from topical mitomycin, extending to the very serious complications of scleral 
ulceration, secondary glaucoma, corneal oedema or perforation, and cataract. ${ }^{1,2,7,16-18}$

The improvement in recurrence rates with conjunctival autografting or topical mitomycin is very similar and a large trial would be needed to distinguish any difference between them. It has been suggested that such a trial is unjustifiable and that mitomycin therapy is the more appropriate treatment on the basis of its simplicity, lesser expense and relative lack of complications. ${ }^{7}$ This is not a reasonable conclusion. Conjunctival autografting is a technique that is within the grasp of any anterior segment surgeon and, once mastered, it extends the necessary surgical time relatively little. The avoidance of potentially injurious and possibly unobtainable anti-mitotic agents or irradiation makes conjunctival autografting a very attractive procedure to surgeons throughout the world.

In this study, conjunctival autografting was more likely than other forms of surgery to produce an improvement in visual acuity amongst eyes not developing a recurrence. There was no difference in the rate of complications between the various forms of surgery for either primary or previously operated cases and the paucity of complications associated with conjunctival autografting demonstrates that it is a safe procedure. This large retrospective study involving many surgeons at a single hospital in Northern Europe has demonstrated that conjunctival autografting is a safe surgical technique for reducing the probability of recurrence after surgery for pterygium. It can be recommended for the management of either primary or recurrent pterygium and is as effective as and safer than surgery combined with beta-irradiation or mitomycin drops.

The authors are grateful to the other Consultants of the Moorfields Corneal Service for allowing their patients to be included in this study. They are also grateful to Mrs. Jane Fallows for her artwork.

Key words: Conjunctival autografting, Pterygium, Surgery.

\section{REFERENCES}

1. Hayasaka S, Noda S, Yamamoto Y, Setogawa T. Postoperative instillation of low-dose mitomycin $\mathrm{C}$ in the treat- ment of primary pterygium. Am J Ophthalmol 1988;106: 715-8.

2. Singh G, Wilson MR, Foster CS. Mitomycin eye drops as treatment for pterygium. Ophthalmology 1988;95:813-21.

3. Nowell JF. Management of pterygia 20 years later. Southern Med J 1986;79:1382-4.

4. De Keizer RJW. Pterygium excision with or without postoperative irradiation: a double-blind study. Doc Ophthalmol 1982;52:309-15.

5. Meacham R. Triethylene phosphoramide in the prevention of recurrent pterygium. Am J Ophthalmol 1962;54:751-3.

6. Hayasaka S, Noda S, Yamamoto Y, Setogawa T. Postoperative instillation of mitomycin $\mathrm{C}$ in the treatment of recurrent pterygium. Ophthalmic Surg 1989;20:580-3.

7. Singh G, Wilson MR, Foster CS. Long-term follow-up study of mitomycin eye drops as adjunctive treatment for pterygia and its comparison with conjunctival autograft transplantation. Cornea 1990;9:331-4.

8. Kenyon KR, Wagoner MD, Hettinger ME. Conjunctival autograft transplantation for advanced and recurrent pterygium. Ophthalmology 1985;92:1461-70.

9. Steele ADMcG, Kirkness CM. Manual of systematic corneal surgery. Edinburgh: Churchill Livingstone, 1992:62-3.

10. Gardner MJ, Altman DG (editors). Statistics with confidence. London: British Medical Journal, 1989:64-70.

11. Llewallen S. A randomised trial of conjunctival autografting for pterygium in the tropics. Ophthalmology 1989;96: $1612-4$.

12. Tarr KH, Constable IJ. Late complications of pterygium treatment. Br J Ophthalmol 1980;64:496-505.

13. MacKenzie FD, Hirst LW, Kynaston B, Bain C. Recurrence rate and complications after beta irradiation for pterygia. Ophthalmology 1991;98:1776-81.

14. Chen C-W, Huang H-T, Bair J-S, Lee C-C. Trabeculectomy with simultaneous topical application of mitomycin-C in refractory glaucoma. J Ocul Pharmacol 1990;6:175-82.

15. Skuta GL, Beeson CC, Higginbotham EJ, et al. Intraoperative mitomycin versus postoperative 5-fluorouracil in highrisk glaucoma filtering surgery. Ophthalmology 1992;99: 438-44.

16. Yamanouchi U, Takaku I, Tsuda N, et al. Scleromalacia presumably due to mitomycin $\mathrm{C}$ instillation after pterygium excision. Jpn J Clin Ophthalmol 1979;33:139-44.

17. Fukumachi Y, Hikita N. Ocular complication following pterygium operation and instillation of mitomycin C. Folia Ophthalmol Japonica 1981;32:197-201.

18. Rubinfeld RS, Pfister RR, Stein RM, et al. Serious complications of topical mitomycin-C after pterygium surgery. Ophthalmology 1992;99:1647-54. 